LA-UR- 96-2663

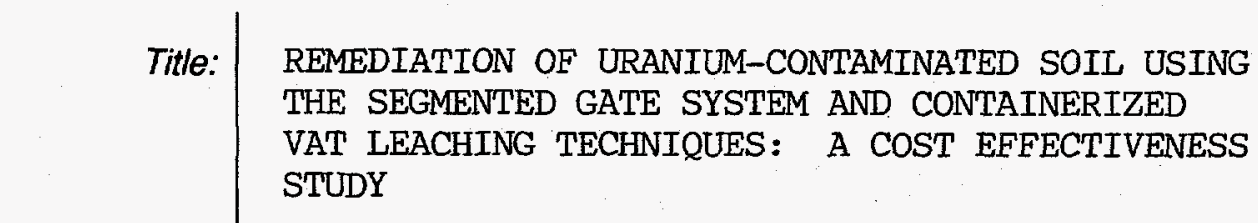

Author(s):

M. Cummings, S. R. Booth

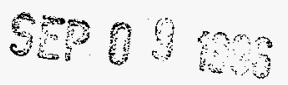

Submitted to:

DOE
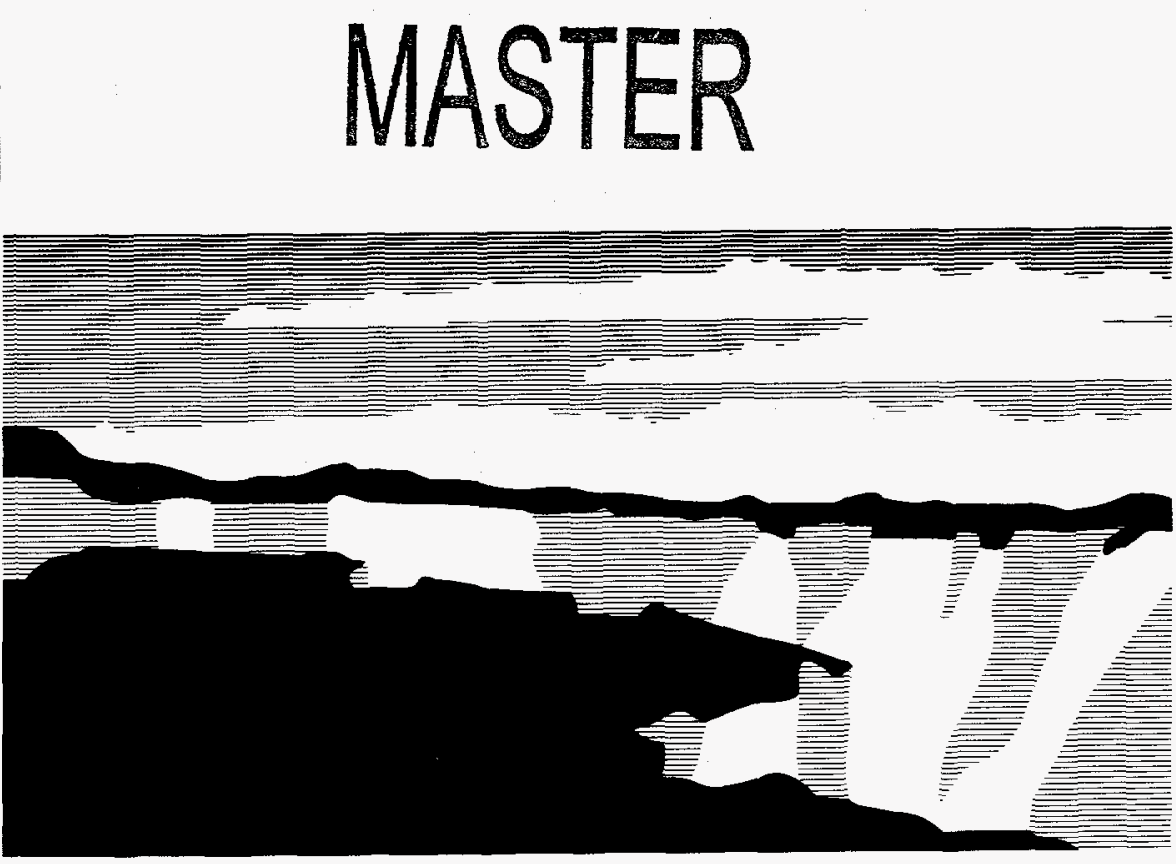

NATIONAL LABORATORY

Los Alamos National Laboratory, an affirmative action/equal opportunity emplơyer, is operated by the University of California for the U.S. Department of Energy under contract W-7405-ENG-36. By acceptance of this article, the publisher recognizes that the U.S. Government retains a nonexclusive, royalty-free license to publish or reproduce the published form of this contribution, or to allow others to do so, for U.S. Government purposes. The Los Alamos National Laboratory requests that the publisher identify this article as work performed under the auspices of the U.S. Department of Energy. 


\section{DISCLAIMER}

Portions of this document may be illegible in electronic image products. Images are produced from the best available original document. 


\section{DISCLAIMER}

This report was prepared as an account of work sponsored by an agency of the United States Government. Neither the United States Government nor any agency thereof, nor any of their employees, makes any warranty, express or implied, or assumes any legal liability or responsibility for the accuracy, completeness, or usefulness of any information, apparatus, product, or process disclosed, or represents that its use would not infringe privately owned rights. Reference herein to any specific commercial product, process, or service by trade name, trademark, manufacturer, or otherwise does not necessarily constitute or imply its endorsement, recommendation, or favoring by the United States Government or any agency thereof. The views and opinions of authors expressed herein do not necessarily state or reflect those of the United States Government or any agency thereof. 


\title{
REMEDIATION OF URANIUM-CONTAMINATED SOIL USING THE SEGMENTED GATE SYSTEM AND CONTAINERIZED VAT LEACHING TECHNIQUES: A COST EFFECTIVENESS STUDY
}

\author{
Mark Cummings \\ Steven R. Booth \\ LA-UR-96-XYZ \\ Los Alamos National Laboratory \\ Technology and Safety Assessment Division \\ Energy and Environmental Analysis Group \\ phone: 505-665-3467 \\ email: mcummings@lanl.gov
}

\section{Conclusions}

- The Segmented Gate System successfully reduced the amount of soil requiring remediation at the pilot test site by $97 \%$.

- The Containerized Vat Leaching System effectively eliminated 95\% (??) of the uranium from the remaining soil.

- $\quad$ SGS/CVL has the potential to save in excess of $\$ 60 \mathrm{M}$ for remediation of each 100,000 cubic yards of radioactively contaminated soil, a cost savings of approximately $75 \%$ over conventional technology.

\section{Summary}

An innovative, two-stage process for the remediation of uranium-contaminated soils was successfully demonstrated at Los Alamos National Laboratory's (LANL) Technical Area (TA-) 33. The first step in the treatment process reduces the volume of the contaminated soil using the ThermoNuclean (a division of the Thermo NUtech company) Segmented Gate System (SGS). This technique involves the use of radiation detectors to separate clean soil from contaminated soil as it moves along a conveyor belt. Contaminated soil is diverted to a separate storage bin to await further processing, while uncontaminated soil is returned to its original location. From the 210 cubic yards of soil excavated from the site at TA-33, only 7 cubic yards were found to contain uranium contamination above the criterion release limit, yielding a waste volume reduction of $97 \%$.

The second step in the remediation was removal of the uranium from the 7 cubic yards of remaining soil using the containerized vat leaching (CVL) process developed at LANL. Borrowing techniques from the mining industry, the uranium was solubilized and collected in solution. Once recovered in the liquid phase, the uranium was subsequently removed from solution using an ion exchange resin. Thus, by using the combined SGS/CVL processes, the total volume of radioactive waste at TA-33 was reduced from 210 cubic yards of contaminated soil to approximately 30 gallons of leachate solution and resins.

A cost effectiveness analysis was performed comparing the above two-stage treatment process to conventional containerization and internment (dig and haul). Results showed that while the 
cost of remediating the small volume of soil at TA-33 was comparable to that using the baseline treatment method, significant cost savings can be realized using SGS/CVL when treating greater volumes of soil.

\section{Introduction}

Because it is difficult to characterize heterogeneously contaminated soils in detail and to excavate such soils precisely using heavy equipment, it is common for large quantities of uncontaminated soil to be removed during excavation of contaminated sites. Until now, volume reduction of radioactively contaminated soil depended upon manual screening and analysis of samples, a costly and impractical approach, particularly with large volumes of heterogeneously contaminated soil. The baseline approach for the remediation of soils containing radioactive waste is excavation, pretreatment, containerization, and disposal (i.e., dig and haul) at an federally permitted landfill. However, disposal of low-level radioactive waste is expensive and storage capacity is limited. ThermoNuclean's Segmented Gate System (SGS) removes only the radioactively contaminated soil, in turn greatly reducing the volume of soil that requires disposal.

The fraction of contaminated soil that remains after processing with SGS is treated via the containerized vat leaching (CVL) system developed at LANL. Uranium is leached out of the soil in solution. The uranium is recovered with an ion exchange resin, leaving only a small volume of liquid low-level waste requiring disposal. The reclaimed soil can be returned to its original location after treatment with CVL. A process flow diagram for the two-stage treatment train is shown in Figure 1.

\section{Potential Cost Savings Across DOE Complex}

The total volume of soil contaminated by radioactive waste across the DOE complex has yet to be accurately quantified; however, DOE's Baseline Environmental Management Report (BEMR) estimates that soil volumes in the millions of cubic yards will require treatment and disposal for radioactive and/or hazardous waste (U.S. DOE, March 1995). According to the cost comparison show below, SGS/CVL has the potential to save in excess of $\$ 60 \mathrm{M}$ for remediation of each 100,000 cubic yards of radioactively contaminated soil, a cost savings of approximately $75 \%$ over conventional technology.

\section{Site Description}

TA-33 at LANL was selected as a suitable pilot test site for demonstrating the effectiveness of the SGS/CVL processes because it is well-characterized. The uranium contamination was the result of ballistics tests performed during the late 1940s. Uranium slugs were fired from a cannon into a catch box mounted in a hillside. The catch box perimeter was well-defined and comprised a volume of approximately 210 cubic yards of soil. Subsequent excavation of the soil revealed 20 uranium slugs, only 2 of which were completely oxidized. The heterogeneous nature of the contamination indicated that volume reduction based on separation of radioactive from clean soil would be an advantageous and practical first step in the remediation.

\section{Technology Description}

Segmented Gate System: The contaminated soil is excavated via front-end loader and emptied into a hopper. There the soil is introduced to a hammermill to break up chunks and rocks so that soil particles are relatively uniform in size. The soil is transported via conveyor belt underneath two banks of sodium iodide scintillation detectors which transmit data to a host 


\section{SGS/CVL Treatment Train for Radioactively Contaminated Soil}

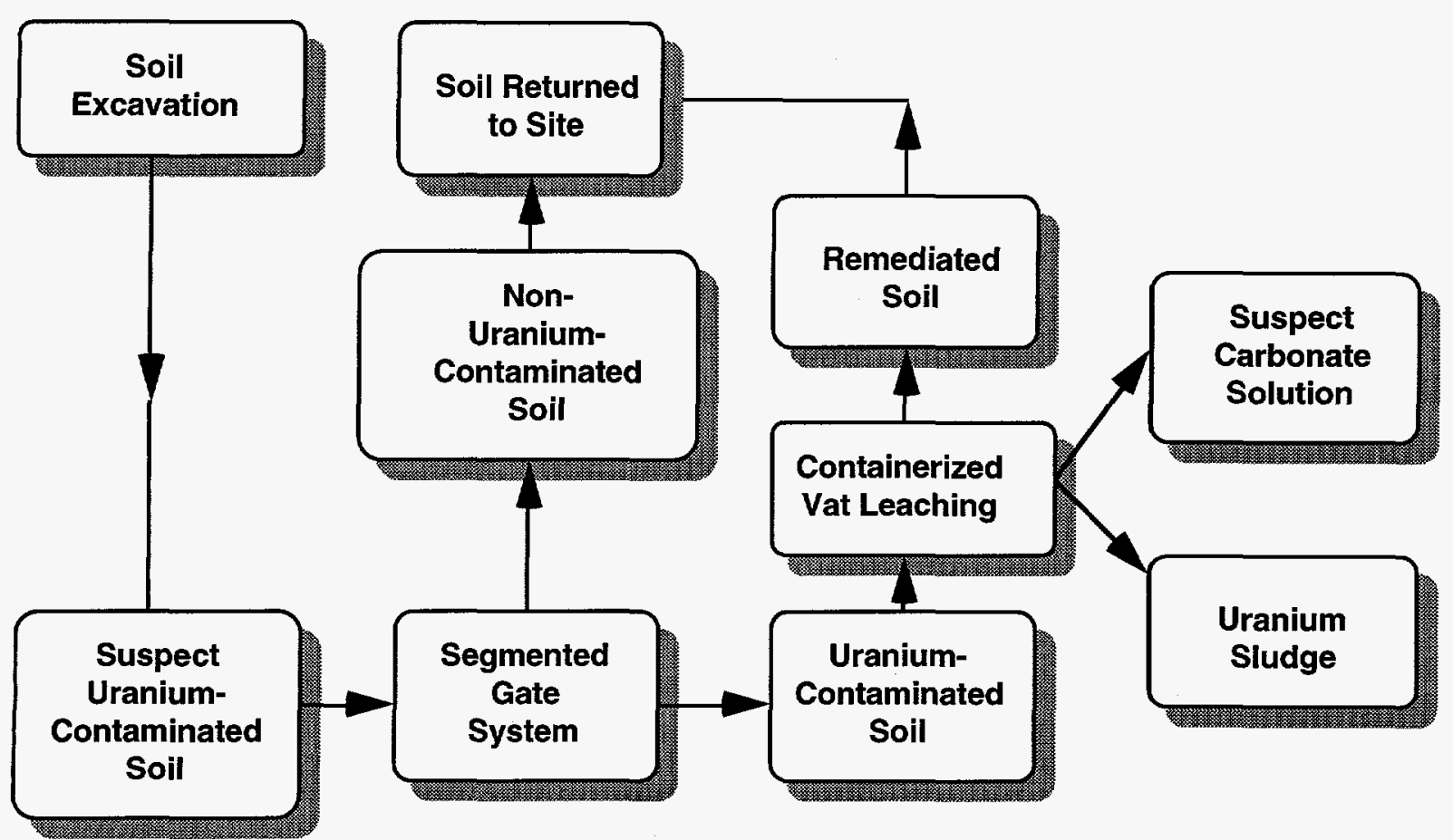

\section{Figure 1. Process flow diagram showing soll separation and TREATMENT VIA SGS/CVL (FROM MORONEY, ET AL., 1994).}

computer that evaluates the amount of contamination in the soil. The computer then controls the operation of mechanical gates that direct small streams of soil to separate paths depending on the amount of radioactivity present. Contaminated soil is collected and containerized for further processing while clean soil is returned to its original location as shown in Figure 2. Cumulative records are kept on a daily basis of total soil mass and radioactivity for both contaminated and uncontaminated soils.

At Johnston Atoll, a military base in the South Pacific, SGS was demonstrated to successfully process over 55,000 tons of plutonium-contaminated soil, achieving a volume reduction of greater than 98\%. At DOE's Savannah River Site 800 tons of soil were processed by SGS with a volume reduction of $99 \%$ for Cs-137. At the pilot test site at LANL's TA-33, a volume reduction of approximately $97 \%$ was achieved. In all cases, the uncontaminated portion of the soil was able to be returned to its original location. This approach to remediation of radioactively contaminated soils significantly reduces the volume and cost of disposal for radioactive waste.

Containerized Vat Leaching: Radioactive soil is contained in a 1 cubic yard vat hung from a metal frame and suspended over a catch basin. An overhead sprinkler system sprays sodium bicarbonate solution onto the soil from above. The leachate passes through the vat, solubilizing the uranium and releasing it as uranyl carbonate. Once recovered in liquid form, the complexed uranium is subsequently removed from solution using an ion exchange resin 


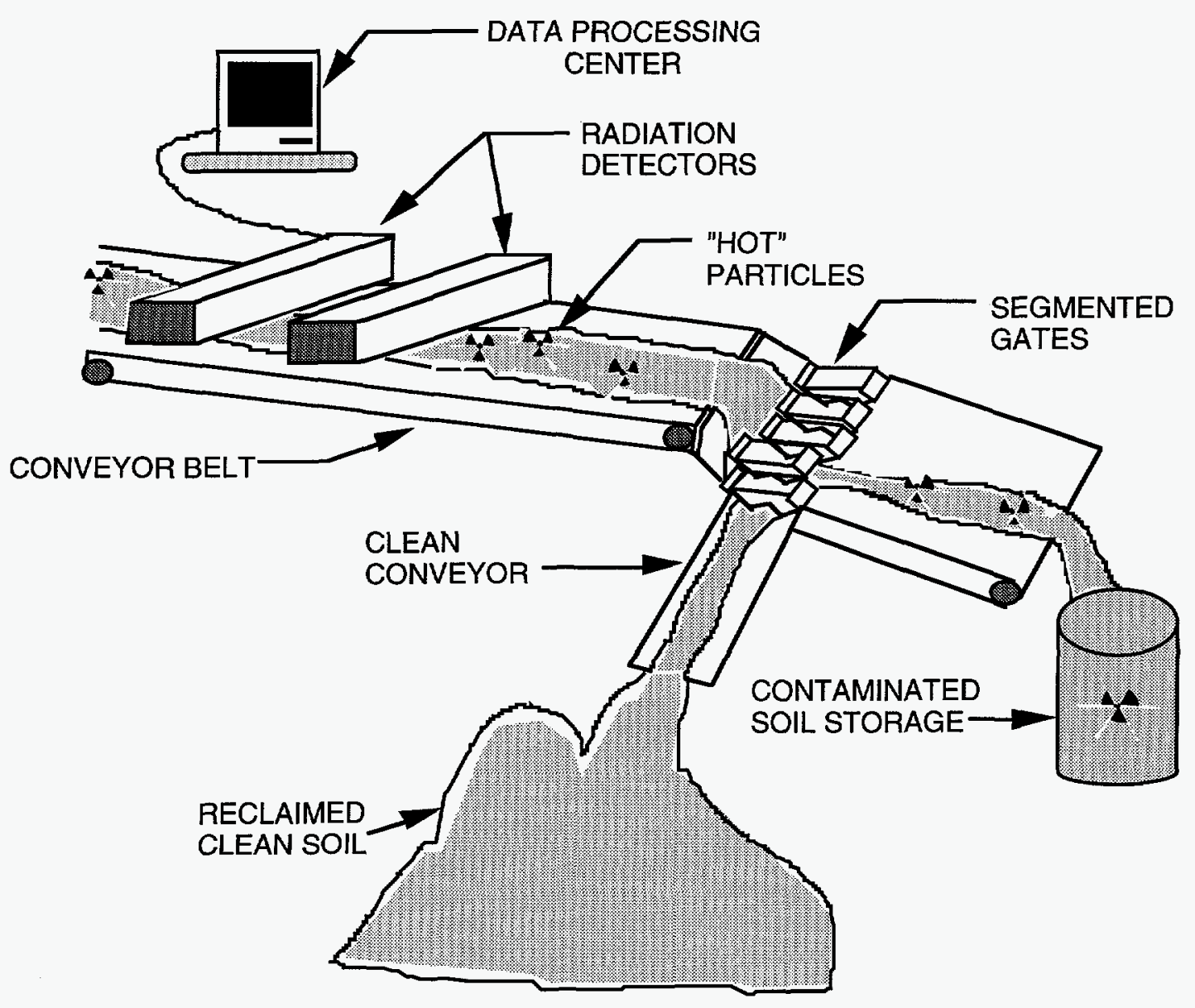

\section{Figure 2. THE SEGMENTEd GATE SYSTEM DIVERTS CLEAN SOIL FROM RADIOACTIVELY CONTAMINATED SOIL (FROM TURNEY, ET AL., 1994).}

while the leachate is recycled through the system (see Figure 3). This method has been successfully used by the mining industry to extract precious metals from low-grade ores. In addition to uranium, the leaching method has been shown to be effective at extracting other radioactive isotopes and hazardous metals; e.g., plutonium, americium, lead, and beryllium (Turney, et al., 1994).

\section{Results of TA-33 Pilot Test}

A total of 210 cubic yards of uranium-contaminated soil was processed at the site using SGS. Processing took two days once the equipment was in place. Of this amount, 7 cubic yards was diverted as being above the criterion release limit (??). This yielded an initial volume reduction of $97 \%$. CVL processing removed $95 \%$ (?) of the uranium in the remaining soil. The fraction removed required 20 (??) cycles of leachate through the system. The current CVL 


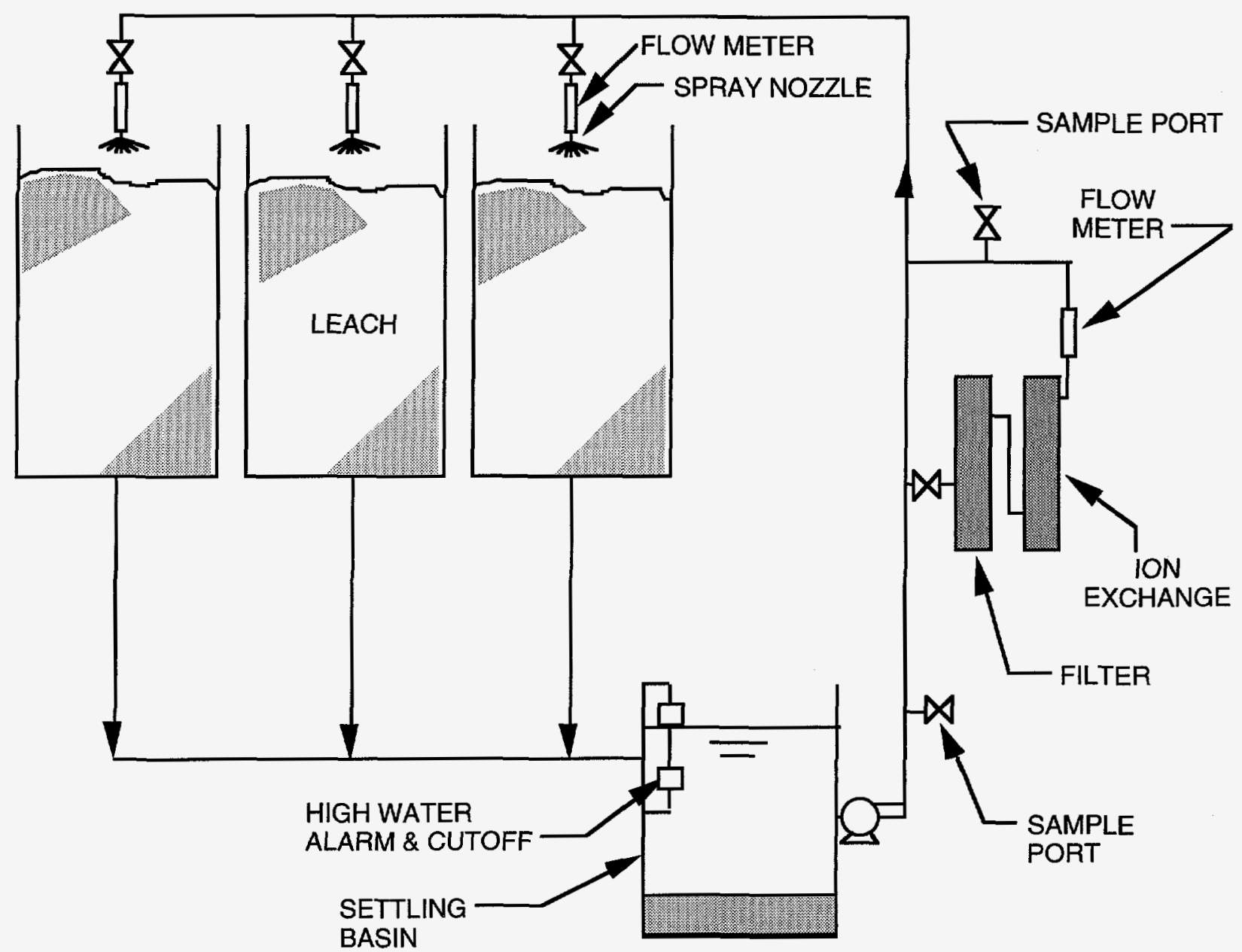

Figure 3. Simplified SCHEMATIC OF THE CONTAINERIzED VAT LEACHING SYSTEM (FROM TURNEY, ET AL., 1994).

configuration at TA-33 allows 3 cubic yards of soil to be processed simultaneously via 3 separate vats as shown above. The average time required to leach out $95 \%$ of the uranium was 21 days. All of the diverted soil was then returned to its original location.

\section{Cost Comparison with Baseline Technology}

SGS operational unit costs depend on the volume of soil processed, and range from approximately $\$ 350 / \mathrm{cu}$. yd. based on the 200 cubic yard volume at TA-33, to about $\$ 50 / \mathrm{cu}$. yd. based on a total volume processed of $40,000 \mathrm{cu}$. yd. (ThermoNuclean cost estimate, June 1996). As a result, total processing costs increase as soil volumes increase, but the unit costs for remediating larger volumes of soil drop dramatically as shown in Figure 4, yielding greater cost savings with increasing soil volumes.

A cost comparison of various technologies for removing uranium from soils performed by Oak Ridge National Laboratory (ORNL) (Douthat, et al., 1994) showed the containerized vat 
Total Processing Cost for SGS as a Function of Soil Volume

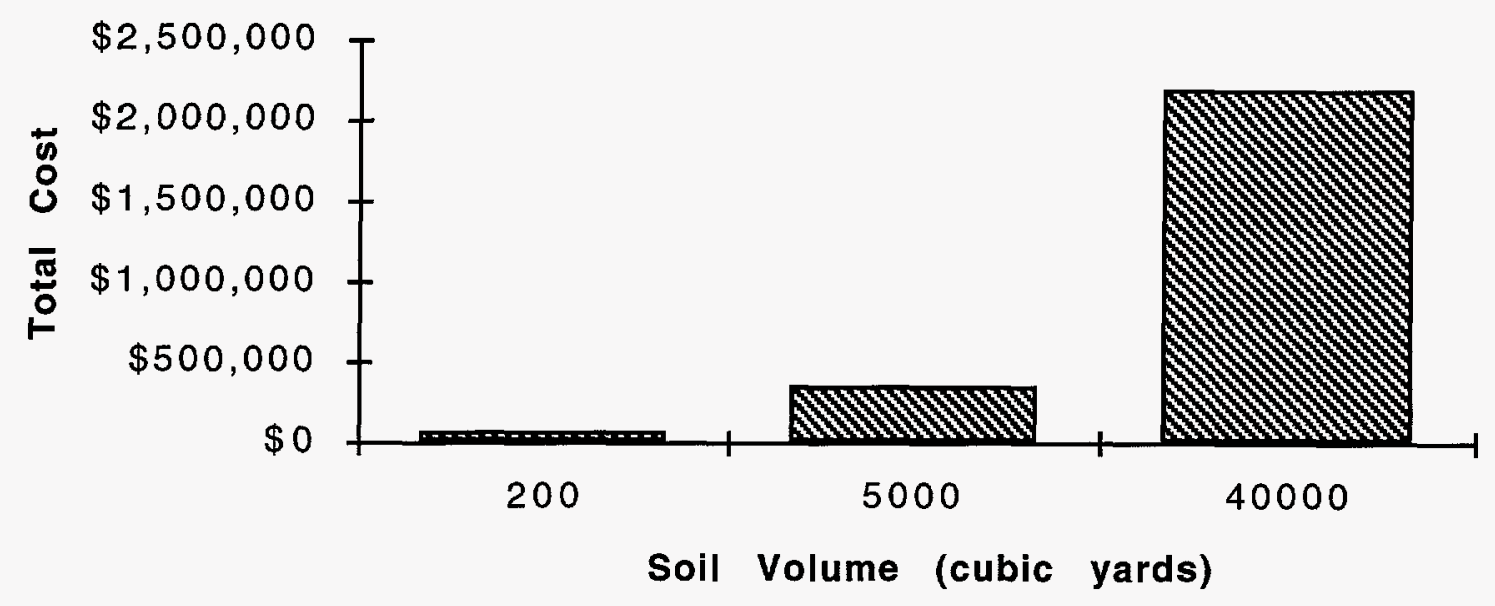

Unit Cost for SGS as a Function of Soil Volume

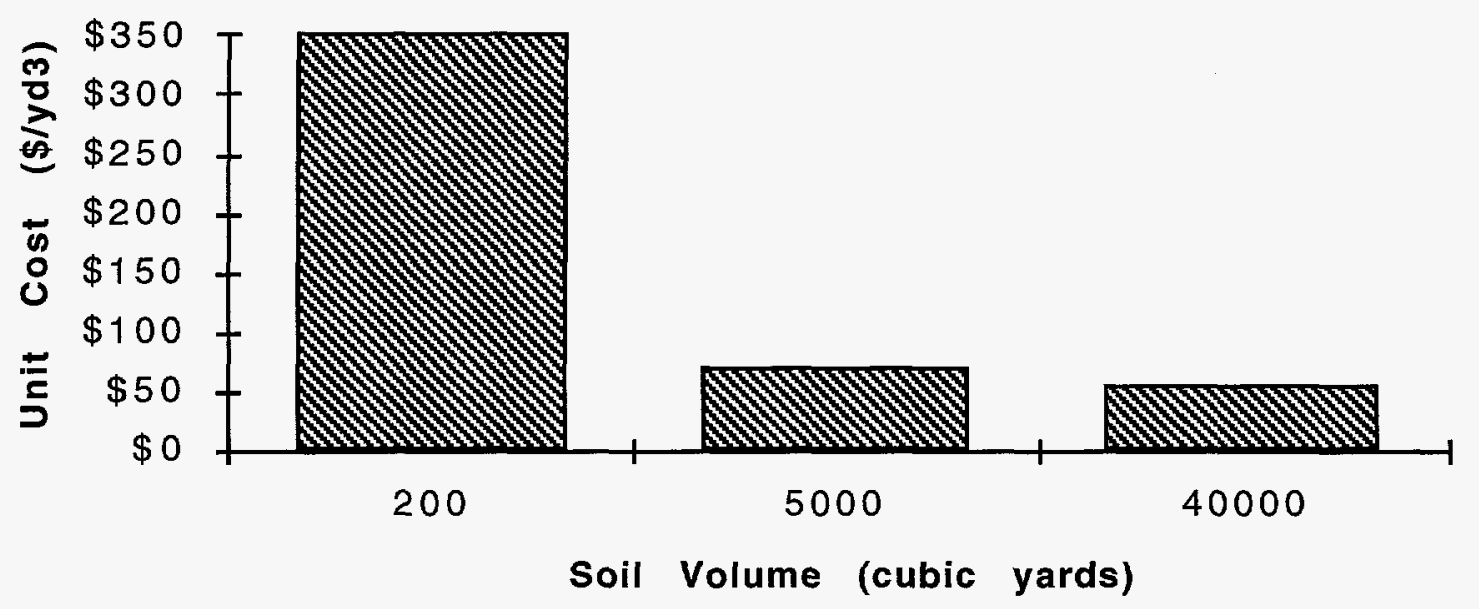

FIGURE 4. SGS TOTAL PROCESSING COSTS INCREASE WITH VOLUME, BUT UNIT COSTS DECREASE WITH VOLUME, YIELDING SIGNIFICANT COST SAVINGS WITH GREATER SOIL VOLUMES (BASED ON THERMONUGLEAN COST ESTIMATES, 1996). 
leaching process for uranium removal to be more cost effective than conventional soil washing, off-site landfilling, or the Tiron ${ }^{\circledR}$ process. Based on the ORNL study, and supported by the pilot test at TA-33 (??), unit costs for CVL are estimated at about $\$ 250 / \mathrm{cu}$. yd.

The baseline approach for the remediation of soils containing radioactive and/or hazardous waste is excavation, pretreatment, containerization, and disposal (i.e., dig and haul) at an federally permitted landfill. Costs for internment of soils containing low-level radioactive waste at an appropriate facility such as Envirocare are approximately $\$ 225 / \mathrm{cu}$. yd. (Romano, January 1996). This does not include the costs of pretreatment (i.e., stabilization and solidification). Transportation costs for low-level radioactive waste are approximately $\$ 300 / \mathrm{cu}$. yd.

Using these estimates, Table 1 compares the costs of using SGS/CVL against conventional dig and haul for the processing of $100,000 \mathrm{cu}$. yd. of uranium-contaminated soil assuming a conservative figure of $80 \%$ initial volume reduction for contaminated soil via SGS. Figure 5 illustrates how cost savings using SGS/CVL increase with increasing soil volume, based on the unit costs for processing $100,000 \mathrm{cu}$. yd. of soil.

table 1. Potential cost savings using SgS/CVl to clean 100,000 CUBIC YARDS OF RADIOACTIVELY CONTAMINATED SOIL.

- Conventional Disposal Costs (Dig and Haul):

- Excavation/Screening =

$\$ 100 / \mathrm{yd}^{3}$

- Transportation = $\$ 300 / \mathrm{yd}^{3}$

- Stabilization/Solidification = $\$ 200 / \mathrm{yd}^{3}$

- Disposal (Envirocare) = $\$ 225 / \mathrm{yd}^{3}$

- Total Unit Cost =

- Total Cost/100K yd yd $^{3}$

- Disposal Costs using SGS/CVL:

- Excavation/Screening: $\$ 100 / \mathrm{yd}^{3}$

Applied to $100 \%$ of volume: $\$ 100 \times 100,000=\$ 10 \mathrm{M}$

- Soil Processing via SGS: $\$ 55 / \mathrm{yd}^{3 *}$

Applied to $100 \%$ of volume: $\$ 55 \times 100,000=\$ 5.5 \mathrm{M}$

- Wet Chemistry: $\$ 250 / \mathrm{yd}^{3}$

Applied to $20 \%$ of volume: $\quad \$ 250 \times 20,000=\$ 5 \mathrm{M}$

- Disposal (Envirocare + Transport): $\$ 225 / \mathrm{yd}^{3}$

Applied to $4 \%$ of volume: $\quad \$ 225 \times 4,000=\$ 1 \mathrm{M}$

- Total Cost/100K yd $\mathrm{yd}^{3}=\$ 21.5 \mathrm{M}$

- Potential Cost Savings for $100,000 \mathrm{yd}^{3}$ soil exceeds $\$ 60 \mathrm{M}$

* Based ThermoNuclean's quote of $\$ 2.2 \mathrm{M}$ for $40,000 \mathrm{cu}$ yd. $\$ 2.2 \mathrm{M} / 40,000=\$ 55$. 


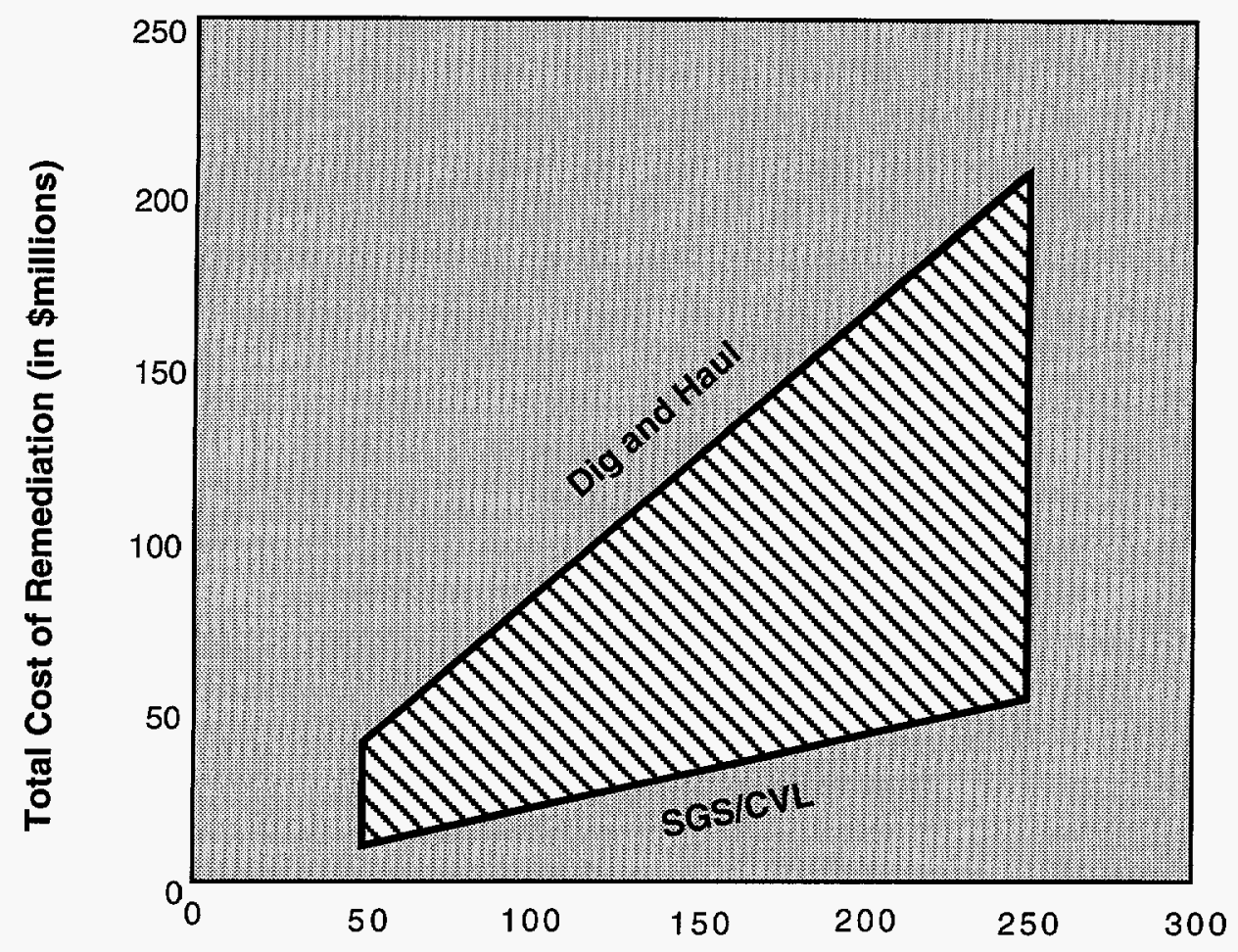

Soil volume ( in 1000's of cubic yards)

\section{Figure 5. POtental cost savings using SGS/CVL Compared to CONVENTIONAL TECHNOLOGY INCREASE WITH THE VOLUME OF SOIL REQUIRING TREATMENT.}

\section{Areas for Further Research}

Los Alamos National Laboratory is currently proposing to demonstrate the SGS/CVL technologies for the remediation of mixed waste. With the addition of laser induced breakdown spectroscopy (LIBS) metals detectors (another technology developed at LANL), the SGS system would have the capability to segregate metals-contaminated as well as radioactively-contaminated soil. The proposed technology demonstration will take place at LANL's R-44 firing site, an area heavily contaminated with uranium, lead, and beryllium.

\section{References}

Douthat, D.M., R.N. Stewart, A.Q. Armstrong, "Fixed Capital Investments for the Uranium Soils Integrated Demonstration Soil Treatment Technologies," ORNL/TM-13004, Oak Ridge National Laboratory, November 1994.

"Estimating the Cold War Mortgage," Baseline Environmental Management Report, U.S. Dept. of Energy Office of Environmental Management, March, 1995.

Hellier, C., ThermoNuclean cost estimate to remediate radioactive soils, personal communication, June 20, 1996. 
Moroney, K., J. Moroney II, J. Turney, and N. Johnson, "Processing PlutoniumContaminated Soil on Johnston Atoll," Radwaste Magazine, July 1994.

Romano, S., personal communication to Steven Booth, Jan. 22, 1996.

Turney, W.R.J.R., D.C. Dander, C.F.V. Mason, D.A. York, S.K. Kung, D.E. Morris, P.A. Longmire, and A.M. Chacon, "Extraction of Uranium, Beryllium, and Lead from

Contaminated Soils at a Weapons Firing Site at Los Alamos National Laboratory," LA-UR-94602, August 1994. Spectrum '94, Atlanta. 